\title{
LIGHT AND TEMPERATURE PARAMETERS TO OPTIMIZE PHOTOSYNTHESIS IN TWO Amaranthus L. SPECIES
}

\section{S.N. DROZDOV ${ }^{1}$, E.S. KHOLOPTSEVA ${ }^{1}$, V.V. KOLOMEICHENKO ${ }^{2}$}

${ }^{1}$ Institute of Biology, the Karelian Scientific Center of Russian Academy of Sciences, 11, ul. Pushkinskaya, Petrozavodsk, 185910 Russia, e-mail holoptseva@krc.karelia.ru;

2Orel State Agrarian University, 69, ul. Generala Rodina, Orel, 302019 Russia, e-mail borpli@rambler.ru

Study was carried out on the equipment of Center for collective equipment use, Institute of Biology, the Karelian Scientific Center of Russian Academy of Sciences

Received January 11, 2012

\section{Abstract}

Among the numerous taxonomic group of Amaranthus L., 12 species are cultivated as vegetable, cereal and fodder crops, medicinal and ornamental plants. A limitation for their introduction in Russia results particularly from lack of data on the physiological and ecological parameters of plant growth and development, which prevents the effective breeding investigations, especially with a view to create varieties for cultivation in northern regions, where the temperatures during spring vegetation are low. In controlled conditions of two factorial preplanned experiment we studied the effect of light intensity and temperature to net photosynthesis in intact Amaranthus cruenthus L. plants (Sultan variety) and A. hypochondriacus L. plants (Krepysh variety). At 6-7 leaf phase, the experimental plants were subjected to hardening for 3 days at $8{ }^{\circ} \mathrm{C}$ and $10{ }^{\circ} \mathrm{C}$ (for A. hypochondriacus and $A$. cruenthus, respectively). To evaluate the $\mathrm{CO}_{2}$ concentration, the infrared gas analyzer Infralyt-IV (SAXON Junkalor GmbH, Germany) was used according to differential scheme. To describe the relationship between $\mathrm{CO}_{2}$ exchange and external factors, the nonlinear equations (a model) were obtained: $N P=a_{0}+a_{1} E+a_{2} T+a_{3} E T+a_{4} E^{2}+a_{5} T^{2}$, with NP as the intensity of observed photosynthesis, $\mathrm{mg} \mathrm{CO}_{2} /(\mathrm{g} \cdot \mathrm{h}) ; \mathrm{E}$ as illumination, $\mathrm{W} / \mathrm{m}^{2} ; \mathrm{T}$ as air temperature, ${ }^{\circ} \mathrm{C} ; \mathrm{a}_{0}-\mathrm{a}_{5}$ as the coefficients calculated basing on the experimental data. A reliability of the equations was verified by the multiple determination index $\left(\mathrm{R}^{2}=85-94\right)$ and $\mathrm{F}$-Fisher test $(\mathrm{F}=4.1-5.6)$ at $\mathrm{p}=0.05$. This model can be applied for estimating photosynthetic activity at definite vegetation phase for each cultivar under different conditions and predicting parameters necessary to achieve definite net photosynthesis even under limiting factors. Thus, using multiple regression analysis, the equations were obtained, which allow estimating favorable combinations of the light intensity and temperature for maximal and optimal net photosynthesis at natural $\mathrm{CO}_{2}$ concentration in the air. In both examined varieties, the net photosynthesis value of 37-38 мг $\mathrm{CO}_{2} /(\mathrm{g} \cdot \mathrm{h})$ was registered as a potential maximum. Sultan variety was more light- and heat-loving, while Krepysh variety demonstrated more coldresistance. The photosynthetic optimum was provided within the limits of $26.7-47.0{ }^{\circ} \mathrm{C}$ and 335 $580 \mathrm{~W} / \mathrm{m}^{2}$ for Sultan variety and at $23.5-39.6{ }^{\circ} \mathrm{C}$ and $284-501 \mathrm{~W} / \mathrm{m}^{2}$ for Krepysh variety. Plant hardening increased their tolerance to low temperature, decreased significantly the peak of net photosynthesis and led to a narrowing the range of light intensity and temperature, necessary to achieve the optimal net photosynthetic parameter.

Keywords: Amaranthus L., preplanned multifactor experiment, net photosynthesis, light and temperature parameters, $\mathrm{CO}_{2}$-exchange.

Amaranthus, the ancient cultivated plant, was first used as food stuff 8000 years ago by the peoples of the American continent. Products made of the grain of amaranth are very nutritious, with taste and flavor similar to those of nuts. Among the numerous taxonomic group of Amaranthus L. 12 species are cultivated as vegetable, cereal and fodder crops, medicinal and ornamental plants.

In Russia N.I. Vavilov initiated study of amaranth in 1930s, but soon this study was ceased and then resumed since 1950s by I.M. Magomedov. Recently this crop is wide spread in North and South America and Asia (1-3). In Russia its introduction is limited by poor ecological and physiological knowledge that prevent breeding, especially in the northern regions with low spring temperatures (4). 
As ecological parameters are recently extremely important for practical goals, their indexes should be used instead of qualitative descriptions $(5,6)$. A labile integrated parameter that allows characterizing $\mathrm{CO}_{2}$-exchnge as a primary productivity should be used to estimate plant response to the environment under controlled conditions of multyfactorial preplanned experiment. Such a parameter should be recorded remotely and continuously with no contact with the plant and also respond quickly to changes in environment. An assessment of the main external factors which provide optimal net photosynthesis is considered as a method to estimate the ecophysiological parameters in plants $(7,8)$. A zonal impact on poikilothermic organisms also should be under consideration, since under the transition to zone, where the quantitative characteristics of the factor differs, its specific influence on the genome can occur leading to metabolic changes (9).

Herein we studied the net photosynthesis in amaranth as influenced by lighting and temperature in the course of multifactor preplanned experiment.

Technique. Amaranthus cruentus L. Sultan cultivar and vegetable amaranth (A. hypochondriacus L.) Krepysh cultivar with different cold resistance and specialization were studied.

The plants were grown in plastic containers $(0.51)$ filled with sandy substrate. From 12 to 15 calibrated germinated seeds were planted into each container. Luminescent lamps $\left(110-120 \mathrm{~W} / \mathrm{m}^{2}\right)$ with 14 -hour photoperiod at $20 / 18{ }^{\circ} \mathrm{C}$ (day/night) were applied. The Knop's nutrient solution supplemented with microelements ( $\mathrm{pH}$ 6.2-6.5) was daily used. The plants with low growth and visible abnormalities were removed, remaining 10 plants in each container.

At the phase of 6-7 true leaves the plants were undergone the hardening for 3 days at $8{ }^{\circ} \mathrm{C}$ and $10{ }^{\circ} \mathrm{C}$, the specific temperatures preliminary identified for vegetable amaranth and $A$. cruentus, respectively. Changes in cold resistance during the hardening were detected as the temperature causing $50 \%$ death of the cells in leaf fragments frozen for 40 min (micro thermostat TZhR-02/02, Interm Co., Russia) and then incubated at gradually increased temperature with $0.4{ }^{\circ} \mathrm{C}$ increment (10). Cell viability was assessed by the light microscope LOMO MIKMED-2 (Russia). Containers with the control and hardened plants were alternatively placed into the device for $\mathrm{CO}_{2}$-echange evaluation (11) to study the influence of both illumination $\left(150,250\right.$ and $\left.350 \mathrm{~W} / \mathrm{m}^{2}\right)$ and temperature $\left(10,20\right.$ и $\left.30^{\circ} \mathrm{C}\right)$ in thrice-repeated two factorial experiment which was carried out according to three level plan (12) at 9 steps.

$\mathrm{CO}_{2}$ concentration was assessed on a photoacoustical infrared gas analyzer Infralyt-IV (SAXON Junkalor GmbH, Germany) at differential scheme. After 40-60 min incubation at each step the $\mathrm{CO}_{2}$ exchange in the plant was calculated as the difference between $\mathrm{CO}_{2}$ input and output with respect to the rate of atmospheric air input, being normalized per plant dry weight.

Data was processed by multiple regression analysis using software package KyPlotStatistics v. 2.0 and Microsoft Excel.

Results. The nonlinear equation was obtained as a model to describe the interrelations between $\mathrm{CO}_{2}$ exchange and the environmental parameters:

$$
N P=a_{0}+a_{1} E+a_{2} T+a_{3} E T+a_{4} E^{2}+a_{5} T^{2},
$$

with NP as apparent photosynthesis, $\mathrm{mg} \mathrm{CO}_{2} /(\mathrm{g} \cdot \mathrm{h}) ; \mathrm{E}$ as illumination, $\mathrm{W} / \mathrm{m}^{2}$; $\mathrm{T}$ as air temperature, ${ }^{\circ} \mathrm{C} ; \mathrm{a}_{0}-\mathrm{a}_{5}$ as coefficients calculated from the experimental data obtained.

The equation reliability was tested by $\mathrm{R}^{2}=85-94$ and $F$-criterion $\mathrm{F}=4.1$ 5.6 at a significance level $\mathrm{p}=0.05$.

The obtained regression model allows evaluating apparent photosynthesis as related to the specific phase of plant development for each cultivar under 
varying conditions and calculating combinations of the factors providing a specified photosynthetic activity even under external limitations.

In intact and hardened plants we estimated the maximum photosynthesis value at natural $\mathrm{CO}_{2}$ concentration in air, and also the optimal zone for $90 \%$ of the maximum and the corresponding light and temperature parameters. It should be noted that in nature the combination of factors providing for maximum apparent photosynthesis is very rare. Active growth and development of plants mainly take place within the optimal zone $(13,14)$, the ecological parameters of which are specified as an ecological niche for the ecotype $(7,8)$. However in some regions the night temperature is significantly lower having a hardening effect, especially on heat loving plants, and affecting the ecological parameters of plant $\mathrm{CO}_{2}$ exchange.

The highest potential net photosynthesis values in intact Sultan and Krepysh plants were 37.5 and $37.8 \mathrm{mg} \mathrm{CO} /(\mathrm{g} \cdot \mathrm{h})$, respectively, the Sultan plants being more heat and light loving with more wide optimal zone, especially within elevated temperatures, if compared to Krepysh plants (Table).

Experimental net photosynthesis and corresponding illumination and temperature conditions in two amaranth species at 6-7 true leaves under cold hardening

\begin{tabular}{|c|c|c|c|c|c|c|c|}
\hline \multirow{3}{*}{ Species, cultivar } & \multirow{3}{*}{ Variant } & \multicolumn{6}{|c|}{ Net photosynthesis } \\
\hline & & \multicolumn{3}{|c|}{ maximum } & \multicolumn{3}{|c|}{ optimum } \\
\hline & & NP & $\mathrm{T}$ & $\mathrm{E}$ & NP & $\mathrm{T}$ & $\mathrm{E}$ \\
\hline \multirow[t]{2}{*}{ Amaranthus cruentus L., Sultan } & Control & 37,5 & 36,8 & 459 & $>33,8$ & $26,7-47,0$ & $335-580$ \\
\hline & Hardening & 15,8 & 24,1 & 303 & $>14,3$ & $17,7-30,5$ & $218-388$ \\
\hline A. hypochondriacus L., & Control & 37,8 & 31,5 & 393 & $>34,0$ & $23,5-39,6$ & $284-501$ \\
\hline Krepysh & Hardening & 10,4 & 21,1 & 323 & $>9,6$ & $15,9-26,2$ & $226-420$ \\
\hline
\end{tabular}

In Sultan cultivar the maximal net photosynthesis was at $36.8{ }^{\circ} \mathrm{C}$ and $459 \mathrm{~W} / \mathrm{m}^{2}$, and in Krepysh cultivar it was at $31.5^{\circ} \mathrm{C}$ and $393 \mathrm{~W} / \mathrm{m}^{2}$. Both cultivars were frost resistant and survived after short freezing at $\leq-4{ }^{\circ} \mathrm{C}$. Krepysh cultivar was more tolerant because its hardening occurred at lower temperature.

Cold hardening decreased sharply both the net photosynthesis and the impact of the temperature, especially low positive temperatures, on the photosynthetic indexes (Fig. 1). Earlier it was shown $(15,16)$ that lower net photosynthesis in hardened plants may be due to more active respiration, in particular to the maintenance respiration as a key component.

After hardening, the exposure of less heat loving Krepysh plants to $35^{\circ} \mathrm{C}$ led to the negative balance in $\mathrm{CO}_{2}$-exchange independently of the illumination parameters. The curves for not hardened plants of both cultivars were clearly dome shaped, with the peaks shifted to higher illumination, $400 \mathrm{~W} / \mathrm{m}^{2}$, when the temperature rose.

The curves reflecting relationship between net photosynthesis and temperature in two-factor experiment under the controlled conditions also approached the dome shape (Fig. 2). Consequently, in one factor experiments, the net photosynthesis plateau at an increased illumination is due not to light saturation as it was suggested $(13,17)$, but to a limiting factor, presumably temperature. One more contradiction arises from the fact that an excessive lighting leads to singlet oxygen generation having destructive effect on the photosynthetic system (18). At the same time the curves for both cultivars have confirmed the need to increase the illumination at high air temperatures (see Fig. 2). So, the cold hardening increased cold resistance in plants and changed the effect of lighting, especially at low temperatures. 


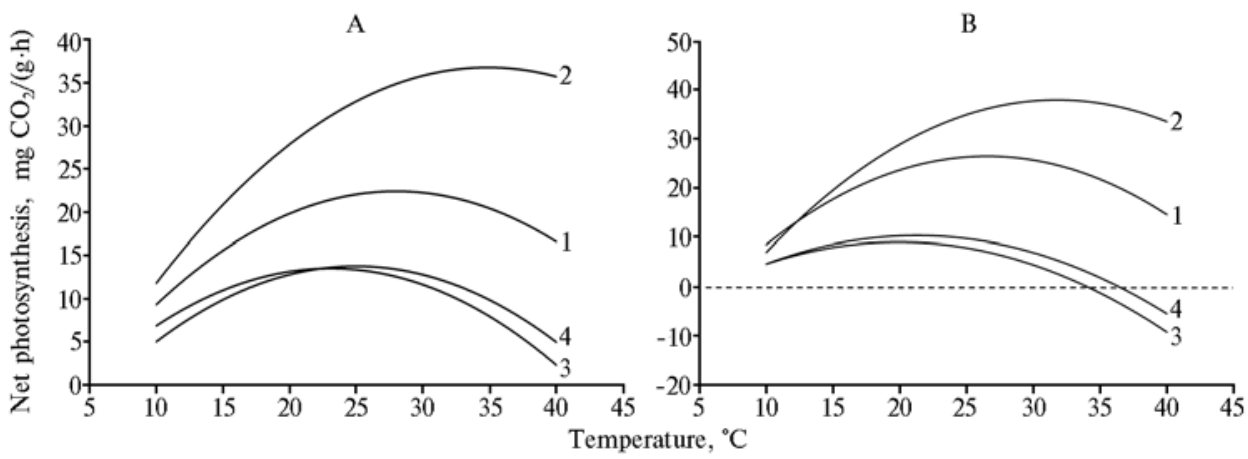

Fig. 1. Net photosynthesis in plants of amaranth Amaranthus cruenthus L. Sultan cultivar (A) and A. hypochondriacus $\mathrm{L}$. Krepysh cultivar (Б) at 6-7 true leaves depending on air temperature: 1 and $2-$ intact plants at 200 and $400 \mathrm{~W} / \mathrm{m}^{2}$, respectively; 3 and $4-$ hardened plants at 200 and $400 \mathrm{~W} / \mathrm{m}^{2}$, respectively.
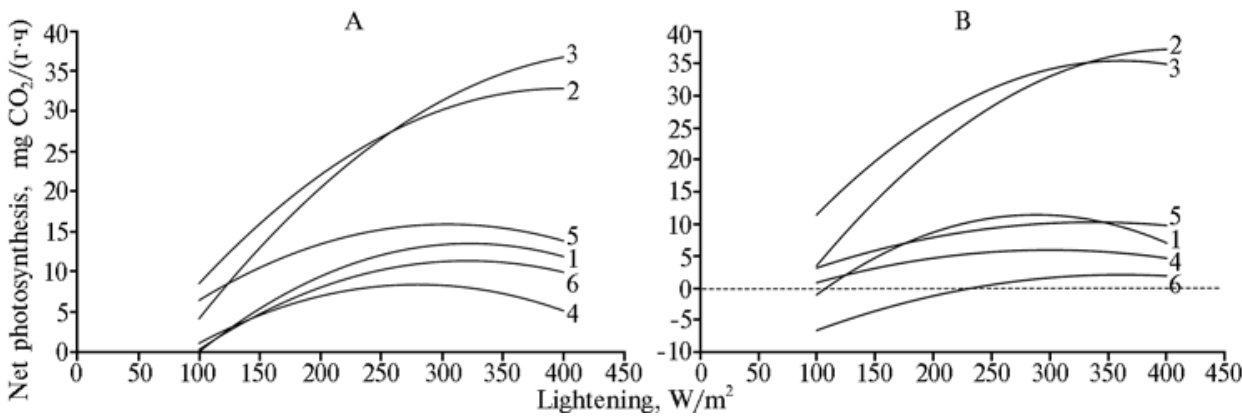

Fig. 2. Net photosynthesis in plants of amaranth Amaranthus cruenthus L. Sultan cultivar (A) and A. hypochondriacus $\mathrm{L}$. Krepysh cultivar (Б) at 6-7 true leaves depending on ligtening: 1, 2 and $3-$ intact plants at 10,25 and $35{ }^{\circ} \mathrm{C}$, respectively; 4, 5 and $6-$ hardened plants at 10,25 and $35{ }^{\circ} \mathrm{C}$, respectively.

So, potential net photosynthetic rates in Amaranthus cruenthus L. Sultan cultivar plants and A. hypochondriacus L. Krepysh cultivar plants under natural $\mathrm{CO}_{2}$ concentration are about the same in value, 37-38 $\mathrm{mg} \mathrm{CO} /(\mathrm{g} \cdot \mathrm{h})$, but could be reached under different lightening and air temperature. The Sultan plants are much more light and heat loving, with the $335-580 \mathrm{~W} / \mathrm{m}^{2}$ and $26.7-47.0{ }^{\circ} \mathrm{C}$ optimal zones during 6-7 true leaf period. The same parameters in Krepysh plants are $284-501 \mathrm{~W} / \mathrm{m}^{2}$ and $23.5-39.6{ }^{\circ} \mathrm{C}$, respectively. In both cultivars the hardening at low positive temperatures $\left(8-10{ }^{\circ} \mathrm{C}\right)$ increases the thermal tolerance, decreases significantly maximum net photosynthetic rates and restricts the temperature and lightening ranges affecting optimal net photosynthesis.

\section{REFEREN C ES}

1. Mago medov I.M., Y a ros he vi ch M.I., C he rnov I.A. Amarant: agrotekhnika vozdelyvaniya i ispol'zovaniya [Amarantus: cultivation and use]. Leningrad, 1980.

2. Z Z e le z o v A.V. Khimiya i zhizn', 2005, 6: 56-61.

3. $\quad \mathrm{M}$ a g o m e d o v I.M. Uspekhi sovremennogo estestvoznaniya, 2008, 5: 57-59.

4. C h i r k o v T.V. Sorosovskii obrazovatel'nyi zhurnal, 1996, 10: 23-27.

5. U r m a n t s e v Yu.A. Fiziologiya rastenii, 1976, 26(4): 762-777.

6. K u r e t s V.K., P o p o v E.G. Statisticheskoe modelirovanie sistemy svyazei rastenie-sreda [Statistical modeling for plant-environment relationship]. Leningrad, 1991.

7. To o $\mathrm{m}$ ing Kh.G. Solnechnaya radiatsiya i formirovanie urozhaya [Insolation and yield formation]. Leningrad, 1977.

8. S u vorova G.G. Fotosintez khvoinykh derev'ev v usloviyakh Sibiri [Photosynthesis in conifers in Siberia]. Novosibirsk, 2009.

9. D rozdov S.N., Ku rets V.K. Nekotorye aspekty ekologicheskoi fiziologii rastenii [Some aspects of ecophysiology of plants]. Petrozavodsk, 2003. 
10. D rozdov S.N., Ku ret s V.K., Budykina N.P., B a lag u rova N.I. V sbornike: $M e-$ tody otsenki ustoichivosti rastenii $k$ neblagopriyatnym usloviyam sredy [In: Estimation of plant tolerance to unfavorable conditions]. Leningrad, 1976: 222-228.

11. Ta la nov A.V., B e zde n e zhnykh V.A., Khilkov N.I. V sbornike: Vliyanie faktorov vneshnei sredy $i$ fiziologicheski aktivnykh veshchestv na termorezistentnost' $i$ produktivnost' rastenii [In: Influence of environment and bioactive substances on thermotolerance and productivity in plants]. Petrozavodsk, 1982: 142-150.

12. Golikova T.I., Panchenko L.A., Fridman M.Z. Katalog planov vtorogo poryadka [Catalog of second-order plans]. Moscow, 1974.

13. L a r k h e r V. Ekologiya rastenii [Plant ecology]. Moscow, 1978.

14. Drozdov S.N., Kurets V.K., T it ov A.F. Termorezistentnost' aktivno vegetiruyushchikh rastenii [Plant thermotolerance under active vegetation]. Leningrad, 1984.

15. Kurets V.K., Drozdov S.N., Popov E.G., Dembo E.D., Khilkov N.I., Tr o f i m ov a S.A. Fiziologiya rastenii, 2003, 50(3): 81-87.

16. Drozdov S.N., S y cheva Z.F., Popov E.G., T a lanov A.A., Kholoptseva E.S., Ku re t s V.K. Fiziologiya i biokhimiya rastenii, 2005, 37(1): 73-78.

17. M a lkin a I.S., T se $l^{\prime} \mathrm{n}$ i k e r Yu.L., Y a ksh in a A.M. Fotosintez $i$ dykhanie podrosta [Photosynthesis and breathing in the undergrowth. Moscow, 1970]. Moscow, 1970.

18. Mokron os ov A.T., G a vrile n k o V.F. Fotosintez. Fiziologo-ekologicheskie i biokhimicheskie aspekty [Photosynthesis. Physiological and biochemical aspects]. Moscow, 1992. 